\title{
STUDI SEMIOTIKA PERANG BANGKAT: ERA TRADISIONAL DAN ERA MODERNISASI
}

\author{
Abdul Shomad \\ Program Studi Pendidikan Sejarah Universitas PGRI Banyuwangi \\ Email: mbahabdulshomad@gmail.com
}

\begin{abstract}
Abstrak
Upacara adat perang bangkat merupakan salah satu bukti keragaman kebudayaan yang ada di Banyuwangi. Adat ini dilaksanakan dalam acara temu pengantin pada suku Osing, namun tidak semua acara temu pengantin menggunakan Upacara Adat Perang Bangkat. Perang Bangkat digunakan apabila pengantin merupakan anak sulung dan bungsu dalam keluarganya. Maksudnya ialah apabila pengantin pria merupakan putra pertama dari sebuah keluarga dan menikah dengan putri bungsu dari keluarga lain harus dilakukan upacara adat Perang Bangkat, begitu pula sebaliknya. Era modernisasi, menyingkirkan adat ini secara perlahan. Terbukti dengan generasi muda lebih menyukai acara pernikahan yang simple dan kebaratan.
\end{abstract}

Kata kunci: adat, Osing, modernisasi

\begin{abstract}
The traditional ceremony perang bangkat is one proof of the diversity of cultures that exist in Banyuwangi. This traditional gathering held in the bride on Osing tribes, but not all gathering brides use perang Bangkat Ceremony. War Bangkat used when the bride is the eldest and youngest child in his family. The idea is if the groom is the eldest son of a family and is married to the youngest daughter of another family have to do ceremonies perang bangkat, and vice versa. Modernization, gradually get rid of this custom. Evidenced by the younger generation prefers the simple wedding ceremony and westernized.
\end{abstract}

Keywords: adat, Osing, modernisasi

\section{PENDAHULUAN}

Banyuwangi merupakan salah satu kabupaten dari Provinsi Jawa Timur yang terletak di ujung timur Pulau Jawa. Wilayah kabupaten ini berbatasan langsung dengan beberapa kabupaten lainnya, secara berurutan di sebelah barat dan utara yaitu Kabupaten Jember, Kabupaten Bondowoso dan Kabupaten Situbondo, di sebelah selatan berbatasan dengan Samudra Indonesia. Sedangkan di sebelah timur berbatasan langsung dengan Selat Bali yang sekaligus sebagai batas Provinsi Jawa Timur sebagaimana di jelaskan dalam artikel Geografi Kabupaten Banyuwangi (Maret, 2010) pada salah satu situs resmi pemerintah Kabupaten Banyuwangi.

Kabupaten Banyuwangi memiliki wilayah yang cukup luas dengan penduduk yang heterogen, terdiri dari berbagai suku seperti, Jawa, Madura, Sunda, Arab dan suku asli Banyuwangi yaitu Suku Osing. Banyaknya suku yang ada membuat Banyuwangi memiliki banyak kebudayaan dan adat istiadat yang berbeda antara desa satu dengan desa yang lainnya. Perbedaan ini biasanya terletak pada jenis adat, tata 
cara, pemaknaan bahkan waktu pelaksanaannya. Karena pada dasarnya kebudayaan merupakan suatu upaya yang dilakukan manusia dalam pemenuhan kebutuhan atas penyesuaian dengan kondisi alam. Sebagaimana dikutip dari Ira Indrawardana 2012 "dikenal suatu konsep bahwa terdapat kaitan erat antara manusia, alam dan kebudayaan sebagai suatu relasi triangulasi". Dalam kebudayaan relasi triangulasi merupakan hubungan yang terjalin antara tiga unsur yaitu manusia, alam dan Tuhan.

Upacara adat perang bangkat merupakan salah satu bukti keragaman kebudayaan yang ada di Banyuwangi. Adat ini dilaksanakan dalam acara temu pengantin pada suku Osing, namun tidak semua acara temu pengantin menggunakan Upacara Adat Perang Bangkat. Perang Bangkat digunakan apabila pengantin merupakan anak sulung dan bungsu dalam keluarganya. Maksudnya ialah apabila pengantin pria merupakan putra pertama dari sebuah keluarga dan menikah dengan putri bungsu dari keluarga lain harus dilakukan upacara adat Perang Bangkat, begitu pula sebaliknya.

Masyarakat Osing mempercayai jika anak sulung menikah dengan anak bungsu maka dalam rumah tangganya kelak akan terjadi banyak masalah atau godaan yang menerpa. Disinilah masyarakat osing merasa perlu dilakukannya Perang Bangkat dalam acara temu pengantin yang dimaksudkan dapat menjauhkan sengkala atau halangan yang sering disebut sebagai Bala dalam rumah tangga yang akan dijalani oleh kedua pengantin. Hal ini dirasakan perlu karena mereka meyakini upacara ini sebagai penolak bala yang wajib dilakukan. Selain itu mereka memahami terdapat pemaknaan dan tujuan dalam upacara adat yang diwariskan oleh leluhurnya.

Pemahaman terhadap pemaknaan suatu adat merupakan hal yang sangat penting baik bagi pengembangan ilmu pengetahuan maupun pengembangan secara menyeluruh khususnya pada komunikasi dan budaya. Dalam suatu budaya terdapat makna yang terkandung didalamnya, baik itu budaya tari, basanan maupun upacara adat. Setiap pelaksanaan upacara adat pasti terdapat perlengkapan-perlengkapan yang harus dipenuhi sebagai syarat kesakralannya. Tidak lain pula halnya dengan upacara adat Perang Bangkat.

Adapun perlengkapan yang digunakan dalam upacara adat Suku Osing ini yaitu berupa beberapa jenis tanaman dan peralatan pertanian serta peralatan rumah tangga. Perlengkapan inimerupakan tanda yang mengandung makna serta pesan yang berusaha disampaikan pada masyarakat umum dan khususnya pada kedua pengantin. Pesan-pesan itu dimaksudkan sebagai 
petuah atau wejangan terhadap kedua pengantin yang akan mengarungi kehidupan baru bersama pasangannya. Selain itu tanda tersebut juga sebagai symbol atas tanggung jawab seorang suami yang menjadi pemimpin dalam sebuah keluarga.

Suatu kebudayaan tercipta dengan berbagai latar belakang yang berbeda, sesuai dengan kondisi alam dan masyarakat yang menciptakannya. Menurut Malinowski, sebagaimana dalam Koentjaraningrat yang dikutip dari Ira Indrawardana (2012), bahwa segala kegiatan atau aktifitas manusia dalam unsur-unsur kebudayaan itu sebenarnya bermaksud memuaskan suatu rangkaian dari sejumlah kebutuhan naluri makhluk manusia yang berhubungan dengan seluruh kehidupannya. Dari pernyataan di atas dapat diketahui bahwa Perang Bangkat sebagai suatu adat memiliki latar belakang, makna dan tujuan yang ingin dicapai.Yakni memenuhi kebutuhan batin yang berupa keyakinan atas hilangnya bala dalam kehidupan sang pengantin. Dengan hilangnya bala dari kehidupan sang pengantin maka akan dapat menghilangkan kekhawatiran atas bencana atau bala yang akan menghidang sehingga dapat menciptakan ketenangan pada diri sang pengantin dalam mengarungi rumah tangganya.

Namun pada era modern ini banyak sekali masyarakat yang tidak mengerti dan memahami bagaimana sejarah, apa makna yang terkandung dan apa tujuan dari Upacara Adat Perang Bangkat tersebut. Ketidakpahaman inilah yang dapat menumbuhkan sikap acuh tak acuh pada setiap individu terhadap salah satu kebudayaan warisan leluhur ini. Hal ini dapat mengakibatkan pergeseran pemaknaan bahkan kemusnahan suatu adat sebagai warisan budaya yang di lakukan secara turun menurun.

Pengaruh modernisasi ini tidak dapat dielakkan dan sangat terasa dampaknya dalam kehidupan masyarakat yang mempengaruhi kelangsungan suatu budaya. Modernisasi yang ditandai dengan penyampaian informasi dengan sangat cepat akan dapat memberikan dampak positif maupun negatif. Namun yang terjadi pada masyarakat saat ini ialah modernisasi telah membetuk karakter baru pada generasi muda. Informasiinformasi politik, ekonomi, bahkan kebudayaan lain telah dapat memalingkan perhatian masyarakat dari kebudayaan dan kearifan lokal.

$$
\text { Informasi-informasi }
$$

tersebut dianggap lebih penting dan lebih dibutuhkan dalam kelangsungan kehidupan mereka. Sehingga intensitas perhatian mereka terhadap budaya lokal sangatlah minim. Dengan minimnya perhatian seperti ini mengakibatkan sedikit sekali generasi muda yang mau 
mempelajari dan menggalih pengetahuan tentang kebudayaan lokal. Pengetahuan dan pemahaman makna terhadap suatu adat oleh generasi muda berpengaruh pada kelangsungan kelestarian adat tersebut. Jika pengetahuan dan pemahaman makna terhadap suatu budaya sangat minim maka kemungkinan keinginan untuk melestarikannyapun akan sangat rendah. Keadaan seperti ini mengakibatkan tidak ada generasi yang dapat melanjutkan pelaksanaan dan melestarikan budaya lokal seperti perang bangkat. Dengan keadaan di atas memungkinkan pada saat ini sangat sedikit sekali masyarakat yang memahami tentang upacara adat perang bangkat.

Suatu penelitian dapat fokus terhadap permasalahan maka dibutuhkan ruang lingkup penelitian dengan jelas. Ruang lingkup ini dapat dibatasi dengan rumusan masalah sebagai berikut yang terkait dengan modernisasi dan pemaknaan perang bangkat.

\section{Pengertian Semiotika}

Semiotik atau ada yang menyebut dengan semiotika berasal dari kata Yunani semeion yang berarti "tanda". Istilah semeion tampaknya diturunkan dari kedokteran hipokratik atau asklepiadik dengan perhatiannya pada simtomatologi dan diagnostik inferensial
(Sobur, 2004:95). Secara terminologis, semiotik adalah cabang ilmu yang berurusan dengan dengan pengkajian tanda dan segala sesuatu yang berhubungan dengan tanda, seperti sistem tanda dan proses yang berlaku bagi tanda (Van Zoest, 1993:1).

Dalam Semiotik Dan Dinamika Sosial Budaya oleh Benny H. Hoed (2014: 5) dijelaskan bahwa Semiotik adalah ilmu tentang tanda. Tanda adalah segala hal baik fisik maupun mental, baik di dunia maupun di jagat raya, baik didalam pikiran manusia maupun sistem biologi manusia dan hewan, yang diberi makna oleh manusia.Jadi, tanda adalah tanda apabila bermakna bagi manusia.

Dalam kehidupan berbudaya disadari ataupun tidak manusia telah menciptakan tanda didalamnya. Tanda yang diciptakan untuk menghubungkan manusia satu dengan manusia yang lain serta tanda yang diciptakan sebagai usaha untuk menghubungkan manusia dengan alam maupun dengan Tuhannya. Hal ini tercipta atas upaya manusia untuk menjaga kelangsungsan kehidupan yang selaras. Begitu pula halnya yang terjadi pada Suku Osing di Desa Gumirih Kecamatan Singojuruh. Masyarakat memiliki banyak budaya baik yang baru tercipta ataupun yang telah diwarisinya secara turun temurun. Salah satu dari hasil kebudayaan tersebut adalah upacara adat perang bangkat. 
Pada upacara adat perang bangkat ini terdapat tanda-tanda yang berusaha dikomunikasikan. Tanda-tanda yang terkandung dalam upacara ini berupa bahasa dan simbol-simbol yang dilambangkan oleh beberapa tanaman dan barang. Tanaman, barang dan bahasa yang digunakan dalam adat perang bangkat dapat disebut sebagai tanda karena memiliki makna atau arti bagi manusia khususnya pelaku budaya. Dalam teori Semiotik terdapat dua pandangan yaitu semiotik struktural dan semiotik Pragmatis.

\section{Adat Perang Bangkat}

Sejarah adat Perang Bangkat tersaji dalam bentuk sejarah lisan. Sejarah lisan menurut Abdul Syukur (2006:1) merupakan penyajian sejarah dalam bentuk lisan yang diberikan secara turun-temurun. Lisan merupakan alat komunikasi utama yang digunakan untuk mewariskan pengetahuan dari zaman dulu ke generasi berikutnya.Namun seiring perkembangan zaman, manusia mulai mewariskan ilmu pengetahuan melalui tulisan pada batu, dinding gua, kayu dan sebagainya hingga pada kertas pada zaman sekarang. Sejarah lisan mulai jarang digunakan karena pengetahuan tertulis dianggap lebih valid dan lebih dapat dipercaya.

Perang Bangkat sebagai suatu adat yang merupakan salah satu hasil kebudayaan manusia tentulah memiliki latar belakang. Terdapat berbagai macam latar belakang atas terciptanya suatu kebudayaan. Latar belakang ini berupa keadaan alam, pengetahuan dan kepercayaan. Hal ini sesuai dengan Julian J. Pattipeilohy dalam penelitiannya tentang Arsitektur Tradisional Tidore Kepulauan (2013:29) yang menjelaskan bahwa suatu adat memiliki tujuan untuk memenuhi kebutuhan sosial, religi dan sebagainya.

Upacara adat Perang Bangkat sebagai bentuk salah satu adat memiliki tujuan yaitu sebagai pemenuhan kebutuhan sosial dan religi bagi kehidupan masyarakat suku osing. Hal ini terlihat dari interaksi serta nilai kesakralan dalam upacaranya.Pelaksanaan upacara adat perang bangkat tidak terlepas dari kepercayaan masyarakat yang meyakini bahwa upacara ini sebagai penolak bala. Sehingga dengan dilakukannya upacara ini maka sang pengantin akan terbebas dari bala.

\section{Era Modernisasi}

Modernisasi dan perubahan sosial adalah sesuatu yang saling berkaitan dan tidak dapat di pisahkan. Modernisasi dan perubahan sosial dalam perjalanan perkembangannya telah menjadi ideologi. Hal ini tidak terlepas dari pengaruh kekuasaan dan dukungan dana dari negara-negara liberal. Sofjan Alizar 
Sam dalam Kegagalan Modernisasi Pembangunan di Indonesia (2014:106107) menjelaskan bahwasannya bantuan negara maju dalam percaturan ekonomi khususnya dari Amerika tidak lain dengan maksud untuk mengambil peran yang dominan dalam percaturan ekonomi dan politik dunia. Bantuan yang ditawarkan oleh Amerika tidak lain adalah untuk kepentingan politik yaitu membendung berkembangnya ideologi komunis yang pada saat itu berkembang pesat. Hingga modernisasi telah menjadi ideologi yang mendunia sampai saat ini.

Perubahan merupakan suatu hal yang wajar dalam kehidupan, pengaruh perubahan ini dapat menjalar dan dirasakan dengan cepat oleh negaranegara lain di dunia. Keadaan seperti ini didukung dengan adanya sistem komunikasi yang modern serta diiringi dengan penemuan-penemuan teknologi baru, revolusi, modernisasi yang kemudian dengan cepat dapat diketahui oleh masyarakat lain yang letaknya jauh dari daerah tersebut.

Ellya Rosana dalam Modenisasi dan Perubahan Sosial (2011:3-4)
menjelaskan bahwa pada dasarnya
bangsa dan masyarakat di dunia ini
senantiasa terlibat dalam proses
modernisasi, meskipun kecepatan dan
arah perubahannya berbeda-beda antara
masyarakat yang satu dengan
masyarakat yang lain. Proses
modernisasi itu sangat luas, hampir- hampir tidak bisa dibatasi ruang lingkup dan masalahnya, mulai dari aspek sosial, budaya, ekonomi, politik dan seterusnya.

$$
\text { Soerjono Soekanto }
$$
merumuskan bahwa perubahan sosial adalah segala perubahan-perubahan pada lembaga-lembaga kemasyarakatan di dalam suatu masyarakat, yang mempengaruhisistem sosialnya, termasuk didalamnya nilai-nilai, sikapsikap, dan pola perilaku diantara kelompok-kelompok dalam masyarakat.

Dari pernyataan diatas dapat diketahui bahwa perubahan terjadi pada setiap kalangan dan lapisan masyarakat, baik masyarakat kota maupun masyarakat desa. Masyarakat pedesaan yang terlihat tidak mengalami perubahan dan cenderung hidup statispun pada dasarnya mengalami perubahan, namun perubahan itu lambat atau bahkan cenderung sangat lambat. Perubahan ini meliputi berbagai aspek serta makna dan nilai yang ada dalam suatu masyarakat. Hal ini dapat ditunjukkan dari perubahan pola prilaku, perubahan sikap dan karakter dalam manusia sebagai anggota masyarakat. Perubahan ini merupakan dampak dari modernisasi.

\section{METODE PENELITIAN}

Lokasi penelitian dilakukan di Desa Gumirih Kecamatan Singojuruh yang mana masih terdapat Suku Osing dan 
melaksanakan adat perang bangkat. Penelitian yang dilakukan merupakan jenis penelitian kualitatif yang mana prosedur yang menghasilkan data deskriptif berupa data tertulis atau lisan di masyararakat.

Objek dari penelitian ini adalah masyarakat Suku Osing khusunya pelaku Adat Perang Bangkat.Pelaku Adat Perang Bangkat yang diambil peneliti adalah pemangku atau pemuka adat yang kopeten atau orang yang dianggap mengetahui serta memahami tentang Adat Perang Bangkat. Fokus penelitian ini diarahkan pada pengkajian tentang budaya yang hidup dalam masyarakat Suku Osing yaitu Adat Perang Bangkat. Sedangkan ruang lingkup yang diteliti adalah makna yang terkandung dalam upacara adat perang bangkat dan pengaruh modernisasi terhadap upacara adat perang bangkat.

Pengumpulan data dilakukan dengan wawancara, dokumentasi dan observasi. Wawancara dilakukan dengan cara berkomunikasi dan berdiskusi dengan beberapa tokoh adat atau pelaku Adat Perang Bangkat. Data yang diperoleh melalui metode penelitian observasi ini dilakukan dengan mencatat kejadian dan fenomena yang terjadi serta mendokumentasikannya yang kemudian akan menjadi sumber data.Adapun observasi padapenelitian ini yaitu peneliti melihat secara langsung proses jalannya upacara adat perang bangkat yang dilakukan oleh tetua adat. dokumentasi yang dapat digunakan diantaranya adalah rekaman dan berbagai tulisan maupun gambar yang sesuai dengan permasalahan dalam penelitian.

Data yang diperoleh kemudian akan dianalisa interkatif melalui tiga tahapan reduksi data, sajian data, dan verifikasi dan menarik kesimpulan (Sutopo, 2006: 120). Ketiga komponen analisis di atas dapat saling menjalin secara baik sebelum, pada waktu, maupun sesudah pelaksanaan pengumpulan data secara paralel. Ketiga komponen tersebut dapat pula aktivitasnya berbentuk interaksi dengan proses pengumpulan data sebagai suatu proses siklus. Dalam penelitian ini peneliti bergerak di antara keempat komponen (tiga komponen analisis data) selama proses pengumpulan data berlangsung, kemudian bergerak di antara reduksi data, sajian data dan mengambil gambaran simpulan atau verifikasi data.

\section{HASIL DAN PEMBAHASAN}

Berdasarkan hasil penelitian, tradisi Upacara Adat Perang Bangkat yang masih dilaksanakan oleh masyarakat Suku Osing merupakan salah satu warisan budaya leluhur yang masih dipertahankan hingga sekarang. Kelestarian budaya ini tidak terlepas dari sejarah kepercayaan mereka yang 
telah mendarah daging. Upacara adat perang bangkat merupakan akulturasi budaya dengan agama Hindu. Hindu merupakan agama awal dari pada masyarakat Osing. Kepercayaan terhadap dewa dan roh-roh nenek moyang sangat melekat bahkan sampai saat ini.Sehingga cerita-cerita pewayangan Hindu sering dikaitkan dalam kehidupan. Seperti dalam kisah perang bangkat yang dijelaskan oleh bapak Suwito selaku pemuka adat di Desa Gumirih Kecamatan Singojuruh. Pasangan pengantin yaitu anak sulung dengan anak bungsu merupakan mangsa dari betara kala, oleh karenanya dilakukan ritual perang bangkat untuk menghilangkan sengkala pada pasangan pengantin. Kebudayaan merupakan hasil cipta manusia yang dilakukan untuk memenuhi kebutuhannya baik kebutuhan jasmani, sosial maupun rohaninya yang dilakukan secara terusmenerus guna mempertahankan hidupnya.

Upacara Adat Perang Bangkat tidak dilakukan pada setiap temu pengantin. Sebagaimana dijelaskan oleh Bapak Suwito Bahwa Upacara Adat Perang Bangkat dilakukan apabila pengantin merupakan anak sulung dengan anak bungsu atau anak bungsu dengan anak bungsu. Hal ini selaras dengan pernyataan Saif dalam prosesi perang bangkat dalam pernikahan suku using Banyuwangi bahwa Pernikahan yang diharuskan melaksanakan tradisi perang bangkat ini, ternyata hanya berlangsung dalam kondisi tertentu saja.Bila kedua pasangan pengantin itu sama-sama anak sulung atau bungsu, maka perang bangkat harus dilaksanakan atau anak sulung yang menikah dengan anak bungsu maka juga harus dilaksanakan upacara perang bangkat. (http://www.academia.edu/4566472/P ROSESI_PERANG_BANGKAT_DALAMPERNI KAHAN_SUKU_USING_BANYUWANGI: diunduh hari Selasa, 26 Mei 2016 jam $11: 33)$

Namun dalam perkembangannya pada saat ini Bapak Suwito mengatakan bahwa sudah jarang dilakukan Upacara adat perang bangkat pada pernikahan anak bungsu dengan anak bungsu atau anak sulung dengan anak sulung.Yang masih dijalankan dalam masyarakat adalah upacara perang bangkat untuk pernikahan anak sulung dan anak bungsu. Pergeseran pelaksanaan upacara ini menunjukkan bahwa perang bangkat sebagai budaya mengalami perubahan. Perubahan ini sebagai dampak dari perubahan manusianya dan pengaruh modernisasi yang masuk dalam kehidupan masyarakat Suku Osing.

Dalam pelaksanaan upacara adat ini terdapat berbagai perlengkapan yang digunakan sebagai syarat keskralannya.Adapun setiap perlengkapan tersebut memiliki makna dan pesan didalamnya. Selain sebagai 
ritual penolak bala adat ini juga memberikan nasehat atau wejangan terhadap kedua pengantin dalam menjalani kehidupan. Makna atau pesan yang terkandung dalam Perang Bangkat menurut Bapak Suwito diantaranya meliputi keloso bantal (tikar dan bantal), wanci, bokor, dan kendi. Adapun perlengkapan lain yang digunakan dalam Upacara Adat Perang Bangkat adalah ingkrek atu ongkek, para bungkil, para pecah, para gumantung dan singkal. Setiap perlengkapan yang digunakan dalam upacara adat ini memiliki makna.

Keloso bantal menggambarkan alas kehidupan dan sebagai tempat untuk istirahat.Dalam kehidupan tempat istirahat adalah rumah. Rumah yang dalam hal ini digambarkan oleh keloso bantal diharapkan dapat menjadi sandaran dalam kehidupan.Untuk itu pemangku adat selalu berpesan agar dalam kehidupan manusia harus teliti dan hati-hati.Selain itu manusia juga harus bersikap jujur, sabar, dan nerimo/legowo (tawakal) untuk menuju kehidupan yang tentram. Selain itu pemangku adat juga menjelaskan bahwa kejujuran digambarkan sebagai jalan yang lurus yang dalam Bahasa Arab disebut dengan sirathal mustaqim. Pelafalan dari akhir kalimat sirathal mustaqim dilakukan dengan menutup mulut, hal ini diartikan bahwa manusia harus berhati-hati dalam setiap perkataan yang diucapkannya. Karena perkataan yang tidak hati-hati akan menimbulkan salah faham yang dapat menimbulkan permusuhan.

Wanci merupakan tempat meletakkan kinangan. Wanci disini dirtikan sebagai waktu yang dalam bahasa jawa kromo disebut wanci. Dalam kinangan terdapat beberapa macam isinya yang diantaranya ada daun sirih yang disebut dengan suruh oleh masyarakat Osing dan kapur yang dikenal dengan sebutan enjet.Suruh diartikan dengan kata weruh, yaitu weruho maring waktu, hukum lan agama.

Kata weruh berarti tahu atau mengetahui. Manusia sebagai mahkluk yang berakal dan berbudaya harus mengetahui dan sadar dengan berjalannya waktu, aturan hukum dan aturan agama.Hukum dan agama adalah hal yang mengatur dan mengikat manusia. Apabila manusia taat pada hukum dan agama maka manusia akan selamat dan terhindar dari sanksi, baik sanksi sosial, sanksi hukum maupun sanksi agama. Jika manusia mengetahui ketiga hal tersebut maka hidupnya akan terasa damai. Selain daun sirih dalam kinangan juga terdapat enjet.

Enjet merupakan rendaman kapur yang sudah lama.Kapur memiliki rasa yang pahit, diharapkan kedua pengantin kelak tidak seperti rasa dari kapur yaitu ojo pahit rundinge. Perempuan dan laki- 
laki yang berasal dari keluarga yang berbeda dengan karakter yang berbeda pula hidup bersama untuk membina satu keluarga bukanlah hal yang mudah. Perbedaan pendapat, pandangan dan keinginan akan sering terjadi dan kerap kali menjadi pemicu perselisihan. Oleh karenanya diharapkan kedua belah pihak dapat mengingat pesan ojo pahit rundinge, yang dapat diartikan jangan merasa enggan untuk berunding.Suami dan istri harus saling terbuka untuk bermusyawarah agar mendapatkan jalan keluar yang baik atas setiap permasalahan yang dihadapi.

Perlengkapan lain adalah bokor. Bokor merupakan tempat seperti nampan yang terbuat dari kuningan.Dalam upacara ini bokor memiliki makna sebagai harga diri. Hal ini dikarenakan bokor terbuat dari logam kuningan, warnanya yang kekuning-kuningan digambarkan seperti emas, dimana emas sebagai logam mulia yang memiliki harga yang sangat tinggi.Dalam kehidupan masyarakaat, kekayaan sering diidentikkan dengan harga diri dan status sosial dari seseorang.

Adapun perlengkapan lainnya yaitu kendi dan banyu adem yang berarti air dingin. Kendi merupakan tempat air yang terbuat dari tanah liat.Tempat air ini digunakan masyarakat jawa dari jaman dahulu.Kendi diartikan sebagai jantung hati dari manusia. Oleh karenanya kendi harus diisi dengan banyu adem yang dalam hal ini diartikan sebagai kalimah Allah. Manusia diibaratkan sebagai kendi yang harus selalu diisi dengan air yang dingin yaitu kalimah-kalimah Allah agar jiwanya senantiasa menjadi tenang.

Selain perlengkapan diatas juga terdapat dedaunan yang digunakan sebagai perlengkapan upacara ini yaitu godong opo dan alang-alang.Kedua daun ini oleh masyarakat jawa diartikan dalam kalimat ora ono alangan opoopo.Arti dari kalimat tersebut adalah tidak ada halangan apa-apa. Maksudnya adalah diharapkan kehidupan yang akan dijalani oleh kedua pengantin tidak mendapatkan halangan atau rintangan apa-apa.

Ingkrek atau disebut juga ongkek oleh masyarakat Oseng merupakan perlengkpan yang paling menonjol dalam pelaksanaan upacara adat Perang Bangkat.Selain karena bentuknya yang lebih besar dari perlengkapan yang lainnya, ingkrek merupakan perlengkapan yang hanya digunakan dalam Upacara Adat Perang Bangkat.Dalam pelaksanaan upacara ini ingkrek di isi dengan berbagai macam benda dan tanaman, yaitu para bungkil, para pecah dan para gumantung.

Ingkrek atu ongkek dalam Upacara Adat Perang Bangkat diartikan sebagai perahu. Dimana kedua pengantin akan berlayar bersama mengarungi samudra 
kehidupan. Selain itu ingkrek atau ongkek juga menggambarkan keseimbangan.Ingkrek merupakan alat bantu tradisional yang akan meringankan pekerjaan manusia untuk mengankut benda. Ingkrek merupakan alat yang harus dibawa dengan seimbang, apabila berat sebelah maka akan susah untuk digunakan. Dalam Upcara Adat Perang Bangkat karakteristik dari ingkrek tersebut di maksudkan bahwa manusia arus seimbang dalam menjalani hidup. Begitu pula dalam berumah tangga harus seimbang antara suami dan istri serta antara kedua belah keluarga besarnya agar kerukunan dalam keluarga dapat tercapai.

Dalam ingkrek terdapat para bungkil, para pecahdan para gumantung.Para bungkil dan para gumantung merupakan macam-macam hasil bumi yang dapat digunakan manusia untuk memenuhi kebutuhan pangannya.Hasil bumi ini memiliki peran yang sangat penting dalam menjaga keberlangsungan kehidupan manusia, karena makanan merupakn sumber energi dari pada manusia.Hal ini menggambarkan bahwa manusia sangat bergantung kepada alam dan diharapkan manusia dapat mengolah hasil bumi dengan sebaik-baiknya serta dapat menjaga lingkungan alamnya.

Para pecah yang merupakan peralatan rumah tangga merupakan alat yang membantu manusia untuk mengolah makanan guna memenuhi kebutuhan pangannya.Para pecah dalam rumah tangga digunakan untuk mengolah hasil bumi menjadi makanan. Dalam perang bangkat para pecah ini diartikan sebagai ilmu pengetahuan. Manusia sebagai makhluk berakal dan berbudaya harus memiliki ilmu pengetahuan agar dapat menjalankan kodratnya sebagai khalifah di muka bumi.Ilmu pengetahuan sangat penting bagi berlangsungnya kehidupan manusia. Dengan ilmu pengetahuan manusia dapat mengolah hasil bumi untuk memenuhi kebutuhan hidupnya.

Singkal adalah peralatan selanjutnya yang digunakan dalam upacara adat ini.Singkal merupakan alat yang digunakan untuk membajak sawah dan mengolah lahan pertanian.Dalam Upacara Adat Perang Bangkat singkal mengandung pesan moral yang sangat kuat.Singkal merupakan alat pertanian yang vital, digunakan pada awal proses dalam bercocok tanam. Pesan yang terkandung dalam symbol singkal ini adalah manusia sebagai makhluk hidup yang membutuhkan makanan harus menanam.Pertanian merupakan sektor yang sangat penting dalam kehidupan manusia.Apabila manusia tidak bertani dan tidak menanam dapat dibayangkan bagaimana jadinya kehidupan. Seluruh manusia akan kebingungan mencari sember makanan. Oleh karenanya 
manusia tidak boleh melupakan sektor pertanian.

Selain perlengkapan yang dijelaskan diatas dalam Upacara Adat Perang Bangkat terdapat juga adat ngosek ponjen.Ngosek ponjen merupakan adat yang dilakukan oleh Suku Osing dalam temu pengantin. Adat Ngosek Ponjen ini dilakukan apabila salah satu dari sang pengantin merupakan anak bungsu dalam keluarganya. Adat ini dilakukan hanya kepada anak bungsu yang menikah. Ponjen merupakan kumpulan uang dan bumbu dapur yang diletakkan dalam kantung berwarna putih.Kantung berwarna putih diartikan sebagai kesucian. Uang dan bumbu dapur yang yang terkumpul dalam kantong putih tersebut merupakan pemberian dari saudara-saudara sang pengantin. Dalam ritualnya pemuka adat akan menjelaskan bahwa didalm kantung tersebut ada pecahan-pecahan uang yaitu sak sen, setali, sesuku dan seringgit. Ini merupakan pecahanpecahan uang pada zaman dulu.Setiap pecahan tersebut mengandung makna dan pesan.

Sak sen berarti satu sen, yang diartikan pengantin laki-laki sebagai kepala rumah tangga harus siap isenisen. Isen isen berarti mengisi, yaitu mengisi daringan(tempat menyimpan beras) maupun kantongan(tempat menyimpan uang) dan mengisi kebutuhan batin dari pasangannya. Dengan kata lain pengantin pria sebagai seorang pemimpin dalam keluarga harus siap memberikan nafkah lahir dan batin pada keluarganya. Sak tali berarti satu tali, yang diartikan bahwa kedua pengantin telah ditaleni. Ditaleni berarti diikat, yakni kedua pengantin telah diikat dalam satu ikatan suci yang sah menurut agama dan hukum negara. Sak suku berarti satu suku, yang berarti bahwa kedua pengantin wes diaku.Yakni kedua pengantin telah diakui sebagai keluarga baik dari keluarga pengantin putri maupun keluarga penganti pria.Selain pengakuan dari keluarga, pengantin ini juga sudah diakui oleh masyarakat sebagai keluarga baru. Hal ini dikarenakan mereka telah sah menjadi suami istri menurut hukum agama, hukum Negara maupun adat. Sak ringgit yang berarti satu ringgit. Dalam hal ini diartikan bahwa kedua pengantin kudu biso nganggityang artinya kedua pengantin harus harus bertanggung jawab atas kehidupannya.

Perlengkapan Upacara Adat Perang Bangkat sangat beragam. Dengan berbagai jenis perlengkapan yang telah dijelaskan diatas terdapat pula perlengkapan lain seperti pitik angkrem yaitu ayam yang mengerami telurnya. Keberagaman perlengkapan upacara ini menggambarkan macemeisine alam (keberamgaman isi dari pada dunia). Perlengkapan ini sebagai pesan bahwa 
manusia sebagai makhluk yang hidup di alam harus makarti maring alam, makarti maring lahir lan makarti maring batin. Arti dari tiga kalimat tersebut adalah megerjakan kewajiban kepada alam, kepada lahir dan kepada batin. Maksudnya adalah manusia sebagai makhluk yang hidup di alam harus menjalankan kewajibannya kepada alam yaitu mengolah hasilnya dan menjaga kelestariannya serta tidak merusak alam.Hal ini dilakukan agar keseimbangan alam tetap terjaga.

Selain itu mengerjakan kewajiban terhadap lahir maksudnya adalah sebagai makhluk sosial manusia tidak dapat hidup sendiri oleh karenanya manusia harus menjaga hubungan dengan sesamanya. Menjaga hubungan baik dengan sesame juga akan memudahkan seseorang dalam mencari rejeki untuk memenuhi kebutuhan hidupnya. Manusia juga harus menjalankan kewajibannya terhadap batin yang berarti manusia sebagai makhluk individu yang berkeyaninan harus senantiasa menjalankan kewajibannya terhadap Tuhannya untuk memenuhi kebutuhan batin yang berupa ketenangan.

Ketiga hal tersebut harus dilakukan oleh manusia apabila ingin menuju urip muktiyaitu kehidupan yang damai sehingga keluarga yang dibinanya akan menjadi keluarga yang sakinah, mawadah dan warrahmah yang dalam masyarakat Osing dikenal dengan urip kang toto, titi lan tenrem.

Selain perlengkapan yang sarat akan makna dalam Upacara Adat Perang Bangkat terdapat suluk, pangkur dan kala. Suluk merupakan doa yang dipanjatkan oleh pemuka adat ketika memimpin jalannya ritual. Doa ini dipanjatkan dalam bahasa jawa yang dilagukan serta ditujukan untuk kedua pengantin.

Pangkur diartikan sebagai pangudi isine Qur'an, yaitu mengupas dan mengkaji isi dari AL-Qur'an. Dalam upacara adat ini pemuka adat memberikan pesan dan gambaran kepada kedua pengantin dengan membacakan ayat-ayat dalam Al-Qur'an sebagai cerminan dan tuntunan. Ayatayat tersebut dihubungkan dengan kehidupan manusia yang diharapkan dapat dijadikan sebagai pelajaran.

Dari pemaparan di atas membuktikan bahwa ada komunikasi yang terjalin dalam pelaksanaan perang bangkat. Makna yang terkandung dalam simbol-simbol dan kata khiasan yang dimaksudkan sebagai pesan kepada pengantin maupun masyarakat umum. Hal ini menunjukkan bahwa terdapat semiotika dalam upacara adat perang bangkat sebagaimana penjelasan para ahli yang menerangkan bahwa semiotika merupakan ilmu yang mempelajari tentang tanda dalam kehiupn manusia. Tanda tersebut baik menurut pandangan 
struktural yang menitik beratkn pada bahasa maupun pandangan pragmatis yang menitik beratkan pada bentuk fisik dari sebuah tanda.

Apapun bentuk tanda, tanda merupakan suatu hal yang dapt digunakan manusia untuk berkomunikasi dengan sesamanya.Oleh karenanya pemaknaan pada setiap tanda berdasarkan kesepakatan sosial yang terjadi dalam masyarakat pengguna tanda.

\section{PENUTUP}

Adat perang bangkat yang masih dilestarikan oleh Suku Oseng di Desa Gumirih Kecamatan Singojuruh merupakan suatu bukti dari akulturasi budaya dengan Agama Hindu. Hal tersebut perlu dilestarikan sebagai sebuah bentuk cinta terhadap budaya dan pembuktian jati diri Suku Osing. Pada adat perang bangkat baik dari pelaksanaan dan barang yang diperlukan, kesemuanya memiliki makna secara semiotika yang terkait dengan kehidupan setelah menikah.

\section{DAFTAR PUSTAKA}

Abdulsyani. 1994. Sosiologi, Skematika, Teori, dan Terapan. Jakarta: Bumi Aksara.

Abdul Syukur. 2005. Ensiklopedi Umum untuk Pelajar. Jakarta: Ichtiar Baru van Hoeve.

Djajasudarma. 2006. Metode Penelitian Sosial. Bandung: RinekaCipta.
Soekanto, Soerjono. 2001. Pokok-Pokok Sosiologi Hukum. Jakarta: Raja Grafindo Persada.

Geografis Banyuwangi. 2010. Banyuwangipermai.blogspot.com/2010/03/ geografi-kabupatenbanyuwangi.html;online;11 Februari 2015

H. Hoed, Benny. 2014. Semiotika Dan Dinamika Sosial Budaya. Depok: Komunitas Bambu.

Hamzah Irawan, Andjrah. 2011. Perspektif Semiotik Tentang Representasi Budaya Feodal Dalam Iklan A Mild Versi Tanya Kenapa Dengan Tema Belum Tua Belum Boleh Bicara; download.portalgaruda.org/article =3011\&at==297; online; 10 Februari 2015.

Indrawardana, Ira. 2012. Kearifan Lokal Adat Masyarakat Sunda Dalam Hubungan Dengan Lingkungan Alam. Jurnal Komunitas Vol. 4 Nol. I. $\mathrm{pp}$ 1-8. http://journal.unnes.ac.id/nju/in dex.php/komunitas.

Julian.J Pattipeilohy. 2013. Arsitektur Tradisional Tidore Kepulauan. Jurnal Penelitian, Vol. 6, No. 5.

Lexy J. Maleong. 2008."MetodologiPenelitianKualita tif". Bandung: RemajaRosdakarya Offset.

Rosana, Ellya. 2013. Hukum Dan Perkembangan Masyarakat. Jurnal TAPIs Vol.9 No.1.

Rohman, Agus. 2013. Pergeseran tokoh adat dalam social budaya dan pembangunan di kelurahan Timbangan kecamatan Indralaya kabupaten Ogan Ili; journal.universitas.sriwijaya.ac.i 
$\mathrm{d} /$ indexphp/view/796; online 10 Februari 2015

Saif_welcomedalam PROSESI PERANG

BANGKAT DALAM PERNIKAHAN

SUKU USING BANYUWANGI

(http: / / www.academia.edu/45664

72/PROSESI_PERANG_BANGKAT_DA LAM_PERNIKAHAN_SUKU_USING_B

ANYUWANGI: diunduhhari

Selasa,26, Mei jam 11:33).

Sobur, Alex. 2004. AnalisisTeks Media.

Bandung: RemajaRosdakarya.

Soerjono Soekanto. 2001. Sosiologi. Jakarta: PT Rajagrafindo Persada

Sofjan Alizar Sam. 2014. Kegagalan Modernisasi Pembangunan di Indonesia (Sebuah Prespektif). Jurnal UNIERA. Vol. 3 No. 1.

Sutopo. 2006. Metodologi Penelitian Kualitatif. Surakarta: UNS.

Sugiyono. 2008. Memahami Penelitian Kualitatif. Bandung: Alfabeta.

Van Zoest, Aart. 1993. Semiotika: TentangTanda, Cara Kerjanya dan Apa yang kita Lakukan Dengannya. Jakarta: Yayasan Sumber Agung. 
Studi Semiotika Perang Bangkat: Era Tradisional..., Abdul Shomad, 103-118 